\title{
Interscapular Pharyngocutaneous Fistula: An Extreme Complication of Cervical Stabilization Surgery
}

\author{
Interskapular Farengokutanöz Fistül: Servikal Stabilizasyon \\ Cerrabisinin Stradıșı Komplikasyonu
}

\author{
Hakan KORKMAZ ${ }^{1}$, Guleser SAYLAM ${ }^{2}$, Omer BAYIR ${ }^{2}$, Emel CADALLI TATAR ${ }^{2}$, Ali OZDEK ${ }^{3}$ \\ ${ }^{1}$ Ylldrrim Beyazıt University, Faculty of Medicine, Department of Otolaryngology, Ankara, Turkey \\ ${ }^{2}$ Ministry of Health Diskapi Yildirim Beyazit Training and Research Hospital, Department of Otolaryngology, Ankara, Turkey \\ ${ }^{3}$ Karabuk University, Faculty of Medicine, Department of Otolaryngology, Ankara, Turkey
}

Corresponding Author: Ömer BAYIR / E-mail: bayiromer@hotmail.com

\begin{abstract}
Pharyngeal and esophageal perforations are rare during cervical spine surgery but can cause significant morbidity. Pharyngeal or eosephageal perforations can occur by several mechanisms and the management of pharyngeal or eosephageal perforation's treatment may become difficult. We report a 41-year-old paraplegic man with an interscapular pharyngocutaneous fistula secondary to cervical vertebral surgery. The diagnosis of posterior fistula was delayed for several months as it was an extremely rare complication. We explored the anterior neck and repaired the perforation on the right pyriform sinus primarily. The fistula tract on the back of the patient was completely healed and the patient started oral feeding in the second week after surgery.
\end{abstract}

KEYWORDS: Interscapular pharyngocutaneous fistula, Eosephagocutaneous fistula, Spinal fractures, Spinal fusion

öz

Servikal spinal cerrahilerde farengeal ve özefageal perforasyonlar oldukça nadir gözlenir fakat ciddi morbiditeye neden olurlar. Farengeal veya özefageal perforasyonlar bazı mekanizmalarla ortaya çıkmakla birlikte tedavi yönetimi oldukça zor olabilmektedir. Biz bu çalışmamızda, servikal vertabral cerrahi sonrasında gelişen interskapular farengokutanöz fistülü bulunan 41 yaşında paraplejik erkek hasta sunduk. Hastanın posterior fistülü, oldukça nadir bir komplikasyon olması nedeniyle birkaç ay gecikmiş idi. Hastaya boyun eksplorasyonu uygulandı ve sağ priform sinüste tespit edilen perforasyon alanı tamir edildi. Cerrahiden iki hafta sonra oral beslenme başlanan hastanın sırtındaki fistül traktının tamamen iyileştiği gözlendi.

ANAHTAR SÖZCÜKLER: İnterskapuler farengokutanöz fistül, Özefagokutanöz fistül, Spinal fraktürler, Spinal füzyon cerrahisi

\section{INTRODUCTION}

Cervical spine fractures are life-threatening complications after several types of trauma to neck. Management by cervical stabilization surgery is the gold standard procedure to minimize the relevant morbidity and mortality. Cervical locking plates are applied through anterior, posterior or combined approaches, whereas the anterior has become the most popular in the recent years. There are many papers about the indications, techniques and complications of these procedures. Esophageal or pharyngeal perforations resulting in pharyngocutaneous fistula are not very rare during cervical plate application by anterior approach (1-7). These perforations if left unrepaired, can cause fistulas that may further result in pneumothorax, mediastinitis, sepsis, and even mortality (5).

We report a very unusual case of interscapular pharyngocutaneous fistula after combined approach cervical stabilization surgery.

\section{CASE REPORT}

A 41-year-old paraplegic man with 3 months history of interscapular drainage was consulted to us from the infectious diseases clinic (Figure 1A). He had had a history of combined anterior and posterior cervical fixation surgery 6 months ago for C6-C8 burst fracture after a car accident. He had continuous pus drainage from the edge of posterior incision, which was handled as chronic wound infection. He was hospitalized and administered parenteral antibiotics for 2 months with no remedy. The patient did not have problem of oral feeding with either liquid or solid foods. There was no apparent drainage of saliva or food products from the wound but scanty pus. Previous esophago-gastroscopy by the gastroenterologists was also reported as normal. We applied methylene blue ingestion test and determined the fistula. We also obtained cervical CT that revealed a small defect of pharynx adjacent to the cervical plate on the right site (Figure 2). Meticulous examination of the back of patient revealed 
two fistulas which contained tiny products of orally ingested foods along the scar of posterior cervical incision. Flexible endoscopic examination was normal and he had also previous tracheotomy. A nasogastric tube was applied and oral feeding was stopped with the expectation of spontaneous resolution of the fistula. Upon the failure of conservative approach after 2 weeks, we decided to explore the fistula surgically. Previous anterior cervical incision was utilized and the right neck was explored and cervical plates were reached. There was a $3 \mathrm{~cm}$ tear on the right pyriform sinus wall and the posterior mucosa was fixated beneath the cervical plate to the prevertebral fascia (Figure 3). After removing the fixation system, the edges of the fistula was freshened, the granulation tissue and fibrosis was cleaned (Figure 4). We had the impression that the fistula tract was extending through the holes of the screws posteriorly. Two-layer repair of the pyriform sinus wall was done by $3 / 0$ vicryl and the fistula was closed water-tight (Figure 5). Nothing except daily wound care was done to the

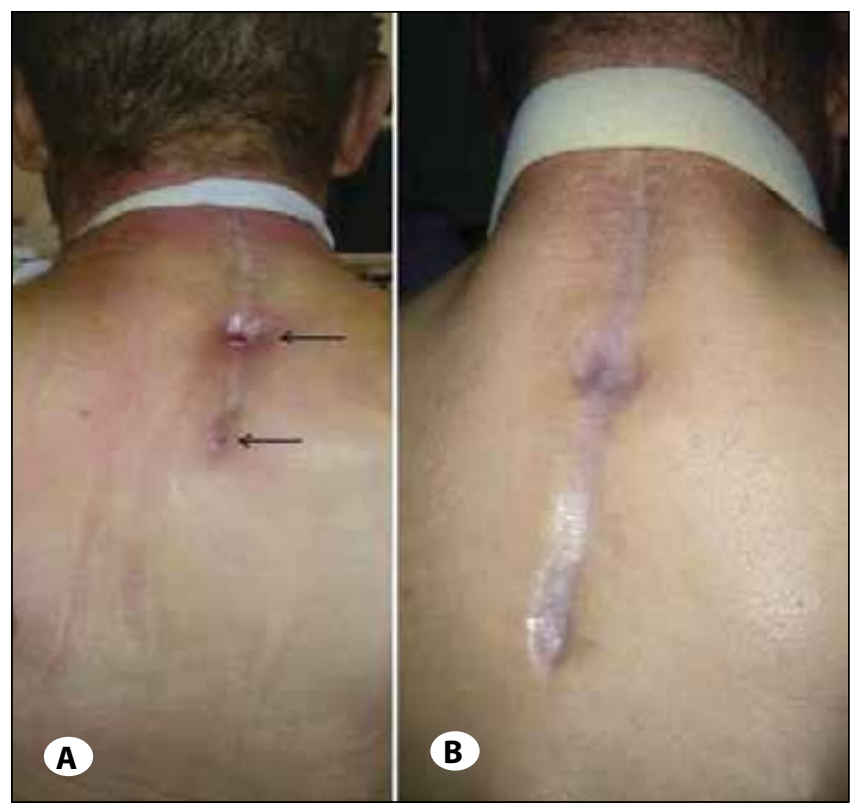

Figure 1: Preoperative and postoperative photographs of his back. A) Two interscapular fistulas on his back (black arrow). B) Three weeks after the surgery; postoperative improvement.

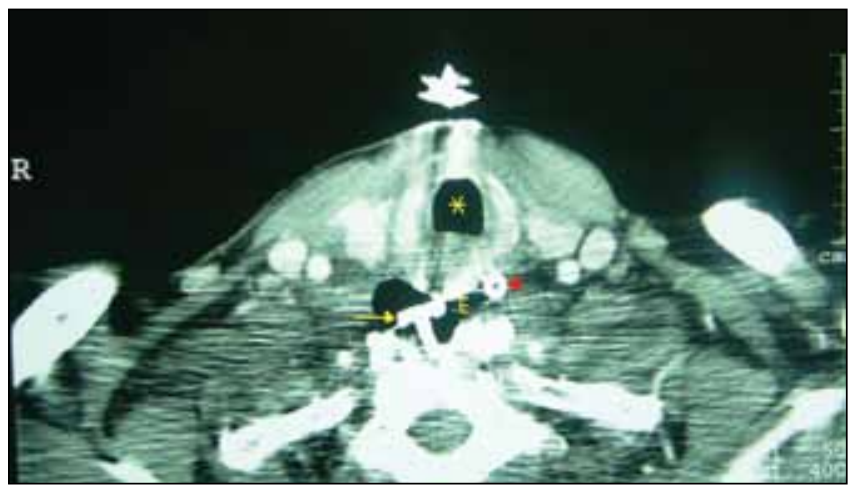

Figure 2: Preoperative thoracal CT. Yellow arrow; screw, ${ }^{*}$; trachea, E; pharynx, red arrow head; nasogastric tube.

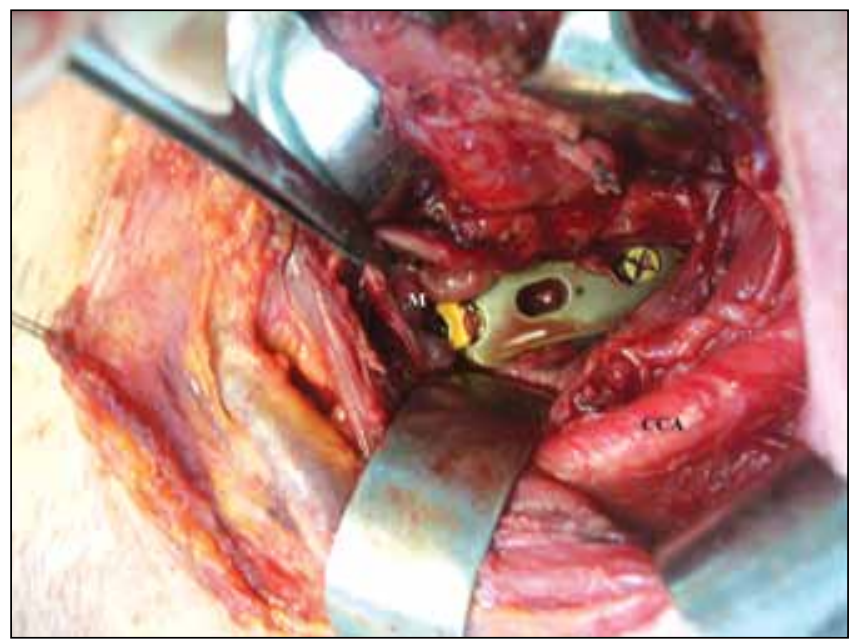

Figure 3: Peroperative figure. *; plaque, $M$; mucosa, CCA; common carotid artery.

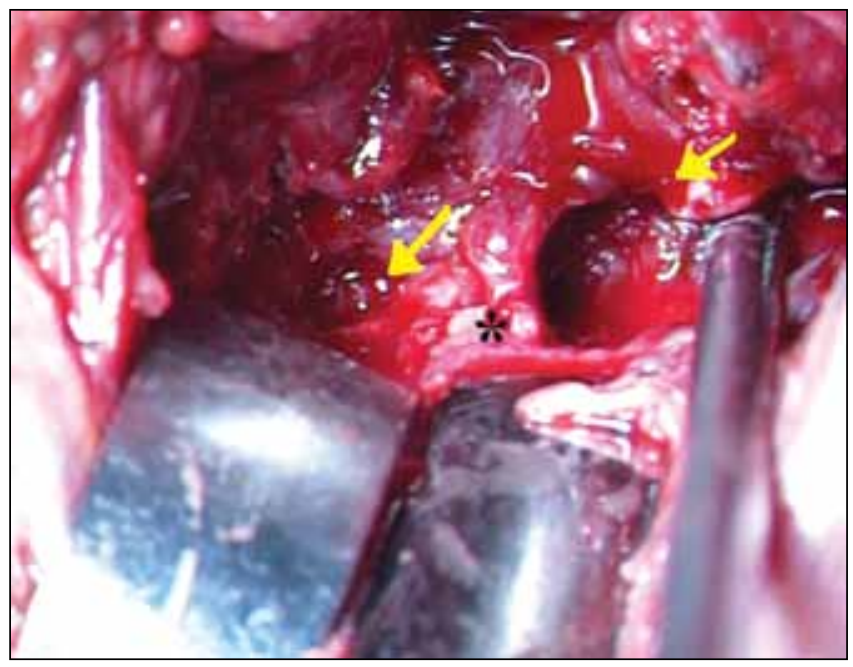

Figure 4: After debridement of the epitelium of the fistula tracts. Yellow arrow; fistula tracts, ${ }^{*}$; vertebrae.

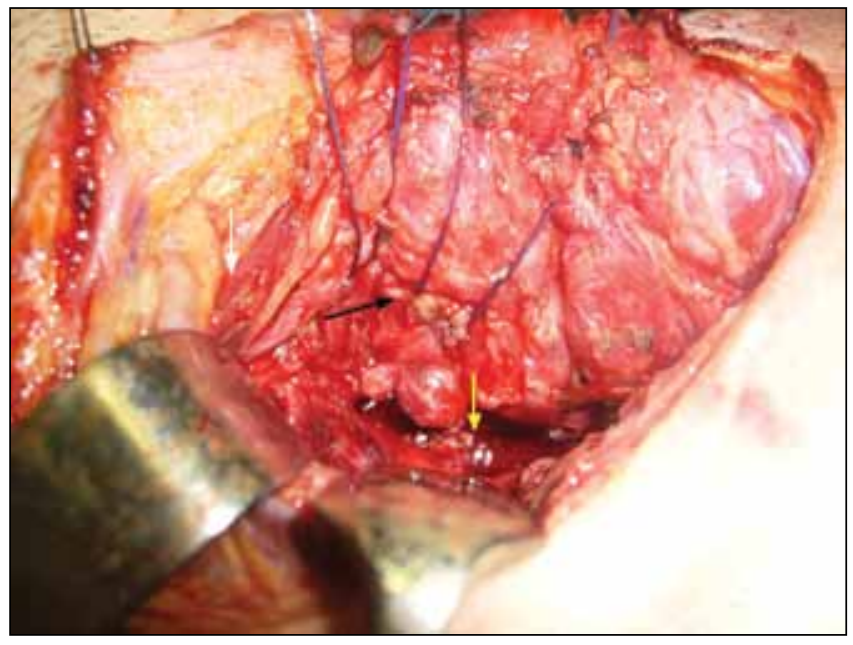

Figure 5: Primary reconstruction of pyriform sinus, peroperative figure. White arrow; omohyoid muscle, blackarrow; reconstruction line, yellow arrow; prevertebral space. 
posterior fistula tract. Nasogastric tube was removed and oral feeding was started one week after the surgery. Three weeks after the surgery, the posterior wound was completely healed and the patient had no problem of oral feeding (Figure 1B).

\section{DISCUSSION}

Vertebral fixation surgery complications can be divided into three groups; biomechanical complications, instant malpositions and tracheoesophageal or neurovascular structural injuries (4). Pharyngocutaneous fistula is a rare but known complication of vertebral surgery and its incidence is between $0.02 \%$ to $1.49 \%$ after the anterior cervical approach $(3,5)$. A search of PubMed for esophagocutaneous and pharyngocutaneous fistula revealed rare cases of anterior neck fistulas but no posterior or interscapular fistula after cervical surgery.

In cervical spine surgery, anterior approach is the most common and combined approach is the rarest. Posterior fistula can only be possible by combined approach. Because pharynx and esophagus are anterior to the cervical spine, and injury to these structures can only happen through anterior approach. It is impossible to have injury to these structures by the posterior approach alone. The injury to upper digestive tract during anterior approach causes perforation and fistula tract finds its pathway naturally to the anterior incision line. Even with the combined approach the expected pathway of fistula tract would be the anterior incision. Therefore, it is very unusual to have posterior fistula after cervical spine surgery. In our patient, right pyriform sinus wall was perforated during plating, and than fistula tract was formed along the dissection plans of posterior insicion. As lateral wall of pyriform sinus is not a dependent part of digestive system a very scarce amount of food was drained along the fistula tract. Our patient had continuous interscapular drainage for several months and the fistula diagnosis was delayed. The reason was the very unusual direction of fistula tract to the posterior route and minimal drainage of pharyngeal contents from the lateral pyriform sinus wall.

Pharyngeal or eosephageal perforations can occur by several mechanisms such as: direct injury during exploration, intubation injury, ischemia secondary to retractors, erosion of digestive tract wall by misinstrumentation $(1-3,7)$. Mortality from this complication is not rare and can be as high as $20 \%$ (5). Therefore, it is very important to notice this kind of injury and repair it properly during the operation.
The presentation, appropriate evaluation, and management of delayed pharyngesophageal perforation from anterior cervical spine hardware application are not well understood because of infrequent reporting, and low incidence. Management of pharyngoesophageal fistula can be achieved either nonsurgically or surgically. Percutaneous drainage, wound care, antibiotics and nasogastric tube insertion are the components of conservative management. Surgical approach includes exploration and debridement of infected and fibrotic tissue off the fistula tract, and then either primary closure or complex reconstruction with flaps $(2,6)$. The literature describes several methods for complex reconstruction, closing the defect with the use of local flaps, omentum or esophageal diversion with jejunum. Sternocleidomastoid muscle, strap muscles, pectoralis muscle have been used for flap reconstruction $(1,3)$.

As a conclusion, esophagocutaneous interscapular fistula after cervical spine surgery has never been reported before. It should be kept in the differential diagnosis of posterior wound drainage after combined approach cervical spine surgery, and managed properly.

\section{REFERENCES}

1. Gaudinez RF, English GM, Gebhard JS, Brugman JL, Donaldson DH, Brown CW: Esophageal perforations after anterior cervical surgery. J Spinal Disord 13:77-84, 2000

2. Kau RL, Kim N, Hinni ML, Patel NP: Repair of esophageal perforation due to anterior cervical spine instrumentation. Laryngoscope 120:739-742, 2010

3. Navarro R, Javahery R, Eismont F, Arnold DJ, Bhatia NN, Vanni S, Levi AD: The role of the sternocleidomastoid muscle flap for esophageal fistula repair in anterior cervical spine surgery. Spine (Phila Pa 1976) 30:E617-E622, 2005

4. Ning X, Wen Y, Xiao-Jian Y, Bin N, De-Yu C, Jian-Ru X, LianShun J: Anterior cervical locking plate-related complications; Prevention and treatment recommendations. Int Orthop 32:649-655, 2008

5. Phommachanh V, Patil YJ, McCaffrey TV, Vale F, Freeman TB, Padhya AT: Otolaryngologic management of delayed pharyngoesophageal perforation following anterior cervical spine surgery. Laryngoscope 120:930-936, 2010

6. Rueth N, Shaw D, Groth S, Stranberg S, D'Cunha J, Sembrano J, Maddaus M, Andrade R: Management of cervical esophageal injury after spinal surgery. Ann Thorac Surg 90:1128-1133, 2010

7. Sansur CA, Early S, Reibel J, Arlet V: Pharyngocutaneous fistula after anterior cervical spine surgery. Eur Spine J 18 : 586-591, 2009 